\title{
Tumour-stroma interactions between metastatic prostate cancer cells and fibroblasts
}

\author{
ANNETTE KAMINSKI*, JENS CLAUS HAHNE*, EL-MUSTAPHA HADDOUTI, \\ ALEXANDRA FLORIN, AXEL WELLMANN and NICOLAS WERNERT
}

Institute of Pathology, University of Bonn, P.O. Box 2120, 53011 Bonn, Germany

Received June 5, 2006; Accepted August 2, 2006

\begin{abstract}
Previous work has shown the importance of tumourstroma interactions for prostate cancer development at the primary site. The aim of the present study was to find out whether evidence can be found for a tumour-stroma crosstalk also between metastatic prostate cancer cell lines and non-prostatic stromal fibroblasts which are encountered by metastatic cells at most sites. We addressed this issue in cell culture systems using 3 metastatic human prostate cancer cell lines (LnCaP, PC-3 and DU-145) on the one hand, and a human fibroblast line (HFF, human foreskin fibroblasts) on the other. We incubated fibroblasts with tumour cell- and tumour cells with fibroblast-conditioned media and evaluated several parameters important for the establishment of metastases such as cell proliferation, migration and expression of matrix degrading proteases. We also determined in the conditioned media the concentrations of several growth factors and cytokines which might be responsible for the observed effects. We found that media conditioned by all 3 metastatic prostate cancer cell lines stimulated fibroblast proliferation which corresponds to fibrous stroma induction in vivo. DU-145 cell conditioned media induced in fibroblasts expression of mmp1 mRNA known to be important for tumour invasion. ELISA assays revealed that tumour cells secrete bFGF, PDGF and $\mathrm{TNF} \alpha$ known to stimulate fibroblast proliferation and/or MMP-1 expression. Cultivation of DU-145 carcinoma cells in fibroblast conditioned medium resulted in an enhanced proliferation and anchorage-independent growth of this cell line in soft agar. Fibroblast conditioned medium also increased migration of PC-3 cells in the wound assay and slightly augmented $m m p-1$ expression. KGF (able to stimulate
\end{abstract}

Correspondence to: Dr Nicolas Wernert, Institute of Pathology, University of Bonn, P.O. Box 2120, 53011 Bonn, Germany

E-mail: nicolas.wernert@ukb.uni-bonn.de

${ }^{*}$ Contributed equally

Key words: prostate cancer metastatic, fibroblasts, tumour-stroma interactions proliferation of normal and neoplastic prostate epithelial cells) was secreted by fibroblasts at higher concentrations than by all 3 tumour cell lines. In addition, fibroblasts secreted TNF $\alpha$, bFGF, PDGF, HGF and also VEGF, the most important factor for tumour vascularization. Our results provide evidence that tumour-stroma interactions do not only exist at the primary site but also between metastatic prostate cancer cell lines and their fibroblastic microenvironment. These interactions, which are mediated through secreted factors, affect several steps of the metastatic cascade including proliferation, anchorage-independent growth, migration and the secretion of matrix-degrading proteases.

\section{Introduction}

Prostate cancer is among the most frequent malignancies in industrialized nations and continuous research efforts are undertaken in order to better understand its development and progression. Androgen dependence of this tumour is long known $(1,2)$ (reviewed in ref. 3 ) and epidemiological studies suggest factors in Western life style to contribute to its development $(4,5)$. Linkage analyses point to hereditary prostate cancer genes $(6,7)$ and polymorphisms of so-called modifier genes (related to hormone response, cell protection or DNA repair) may increase the risk of prostate carcinoma (7-9). Several proto-oncogenes such as myc (10), EIF3S3 (11), bcl2 (12) or growth factor encoding genes (13) have been identified. TP53 (14) and PTEN (15) are among tumour suppressor genes shown to be inactivated in prostate cancer. Comparative genomic hybridization $(\mathrm{CGH})$ and loss of heterozygosity $(\mathrm{LOH})$ analyses suggest further oncogenes and tumour suppressor genes (16-20) (reviewed in ref. 21). DNA methylation and histone acetylation may modify the activity of prostate cancer relevant genes (22-24) and signalling pathways (such as Wnt signalling) have been shown to be deregulated (25). Alterations of the proteasome pathway may finally change the degradation of proteins involved in growth or apoptosis (26).

Epithelial stromal interactions are also considered important for prostate cancer development and progression (reviewed in refs. 27,28). Carcinomas in general are composed of two interdependent components: the neoplastic epithelial cells and the supporting tumour stroma, which plays decisive roles in pivotal processes such as tumour proliferation, vascularization and invasion (29-31). An 
epithelial-stromal cross-talk is already necessary for normal prostate development during which the mesenchyme of the urogenital sinus determines growth and differentiation of the prostate glands (27,32-34). Epithelial-mesenchymal interactions are maintained during life (35) and also play important roles in prostate cancer development (36) (reviewed in refs. 27,37). Prostate fibroblasts can influence prostate carcinoma cell growth by modifying proliferation or apoptosis via paracrine mechanisms (38-41). Using SELDI-TOF mass spectrometry we found a number of differences in gene expression at the proteome level not only between normal and neoplastic epithelial cells but also between normal and peritumoural stromal cells (42).

Only early localized stages of prostate cancer can be cured by therapeutic measures such as radical prostatectomy. However, a significant proportion of tumours metastasizes via the lymph or blood stream $(43,44)$. Hematogenous metastases (most frequentl in the skeleton) occur in $\sim 35 \%$ of patients and lead to uncontrollable disease (45-47). The metastatic process comprises many steps such as tumour cell detachment, migration, matrix degradation, vascular transportation and attachment to metastatic sites by tissue-specific adhesion mechanisms $(48,49)$. Proliferation in the new microenvironment and induction of angiogenesis finally lead to continuous growth of metastases (50). During this cascade tumour-stroma interactions are as important as they are for the development of the primary tumour. However, little is known about this cross-talk at metastatic sites.

Tumour-stroma communications consist of multiple dynamic interactions between neoplastic and stromal cells. The complexity of this cross-talk cannot be directly studied in vivo except in transgenic models able to focus at one given factor such as the role of VEGF-C in lymphangiogenesis $(51,52)$. Appropriate in vitro models are cell culture systems which we used in the present work to study tumour-stroma interactions between metastatic prostate cancer cells and fibroblasts.

We used three established metastatic prostate cancer cell lines from both lymphatic and hematogenous metastatic sites [LNCaP, DU-145 and PC-3 (53-55)] on the one hand, and a human fibroblast line (56) on the other, in order to investigate how a tumour-stroma cross-talk may affect important cellular functions during the establishment of metastases such as proliferation, migration and the secretion of matrix degrading proteases.

\section{Materials and methods}

Cell lines. Cancer cells were received from ATCC (American Type Culture Collection). We used the following three human prostate cancer cell lines derived from different metastases: LNCaP from a lymph node metastasis (53), PC-3 from a bone metastasis (55) and DU-145 from a brain metastasis (54). A short description of cell characteristics is given in Table I. Fibroblasts were human foreskin fibroblasts which we had already used and characterized in previous studies (56).

Culture conditions and production of conditioned media. Cells were cultured at $37^{\circ} \mathrm{C}$ in a humidified atmosphere containing $5 \% \mathrm{CO}_{2}$. They were maintained either in Dulbecco's
Table I. Characteristics of the used prostate carcinoma cell lines.

\begin{tabular}{lccc}
\hline Cell line & Origin & $\begin{array}{c}\text { Androgen } \\
\text { responsiveness }\end{array}$ & Tumourigenicity \\
\hline LNCaP & $\begin{array}{c}\text { Human lymph } \\
\text { node metastasis }\end{array}$ & Androgen sensitive & Low \\
& $\begin{array}{c}\text { Human bone } \\
\text { metastasis }\end{array}$ & Androgen independent & High \\
& $\begin{array}{c}\text { Human brain } \\
\text { metastasis }\end{array}$ & Androgen independent & High \\
& & \\
\hline
\end{tabular}

modified Eagle's medium (DMEM, Invitrogen NV, Leek, The Netherlands, DU-145, PC-3 and HFF) or in RPMI-1640 (Invitrogen NV) medium (LNCaP) supplemented with $10 \%$ heat-inactivated fetal calf serum (FCS, Invitrogen NV), $100 \mathrm{U} /$ $\mathrm{ml}$ penicillin/streptomycin and $2 \mathrm{mM}$ L-glutamine (Invitrogen NV). Culture media were completely eliminated by washing with phosphate-buffered saline (PBS, Invitrogen NV) and cells were starved in medium with $0.5 \%$ FCS prior to the production of conditioned media. Conditioned media with $0.5 \%$ FCS were prepared by incubating subconfluent cells $\left(2 \times 10^{5}\right)$ in 24-well plates for $24 \mathrm{~h}$. Media were separately harvested, clarified by centrifugation $\left(2.000 \mathrm{x} \mathrm{g}\right.$ at $4^{\circ} \mathrm{C}$ for $\left.15 \mathrm{~min}\right)$ and stored frozen at $-20^{\circ} \mathrm{C}$ until further use.

Enzyme-linked immunosorbent assay (ELISA) for determination of growth factor and cytokine concentrations. Separately, harvested conditioned media as well as unconditioned control media were examined for the presence of the following growth factors and cytokines by ELISA: EGF (epidermal growth factor), KGF (keratinocyte growth factor), bFGF (basic fibroblast growth factor), PDGF (platlet derived growth factor), $\mathrm{TNF} \alpha$ (tumour necrosis factor $\alpha$ ), and VEGF (vascular endothelial growth factor). Media stored at $-20^{\circ} \mathrm{C}$ were thawed on ice for analysis. Concentrations of growth factors and cytokines were examined by ELISA kits (R\&D Systems, Minneapolis, MN, USA). All determinations were performed in triplicates according to the manufacturer's instructions. Concentrations were determined by comparing the optical density in the samples to standard curves.

Incubation of prostate cancer cell lines and fibroblasts in fibroblast (FCM) and tumour cell (TCM) conditioned media. In order to examine the effects of tumour cell and fibroblast conditioned media on different properties of cancer cells and fibroblasts we incubated cells with the conditioned media for $24 \mathrm{~h}$. All experiments were performed at least in triplicate. Cells cultivated in starvation medium were used as controls.

Proliferation assay. Proliferation of different prostate carcinoma and HFF cells, which had been cultured in conditioned or control media, was determined by a modified MTT test system for living cells $\left(\mathrm{EZ}_{4} \mathrm{U}\right.$, Biomedica, Vienna, Austria). Cells $\left(2 \times 10^{3}\right)$ were cultured in 96-well plates in 


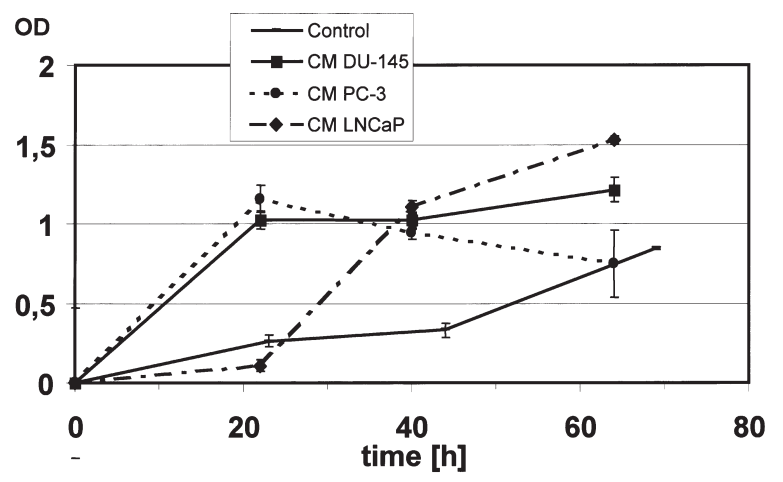

Figure 1. Proliferation of human foreskin fibroblasts (HFF) in tumour cell conditioned media. Proliferation of HFF was determined in prostate carcinoma cell conditioned media (CM) by a modified MTT-test. Cells/well $\left(2 \times 10^{3}\right)$ were cultured in 96 -well plates in $200 \mu 1$ of conditioned or control media for $24 \mathrm{~h}$. The mean values of five independent determinations are shown.

$200 \mu 1$ of conditioned or control medium. The proliferation rates of cells were determined at the time points indicated in Figs. 1 and 4. Each measurement was performed 5 times according to the manufacturer's instructions.

Soft agar assay. For soft agar assays $1 \times 10^{5}$ tumour cells in DMEM and $20 \%$ FCS were mixed with an equal volume of $0.8 \%$ agarose (FMC BioProducts, Rockland, USA). The mixture was poured onto a bed of $1.4 \%$ agarose. The plates were supplied every 3 days with $2 \mathrm{ml}$ of either fibroblastconditioned or starvation medium with $0.5 \%$ FCS and observed for colony formation.

Migration assay. The migratory and motility behavior of the three tumour cell lines was analyzed by the wound assay. Monolayers of confluent cultures were lightly scratched with a pipette tip. After washing to remove detached cells, the cultures were incubated with either fibroblast-conditioned or control media and observed at distinct time intervals.

Invasion assay. Invasion assays were performed in Matrigel Chambers (Becton Dickinson) containing polyethylene membranes with $8-\mu \mathrm{m}$ pore size coated with basement membrane (Matrigel, Becton Dickinson). Cells were harvested by trypsinization, resuspended in conditioned or control media at a density of $5 \times 10^{4}$ cells $/ \mathrm{ml}$ and $2.5 \times 10^{4}$ cells were plated in the upper compartment of the chamber. After incubation at $37^{\circ} \mathrm{C}$ for $22 \mathrm{~h}$ filters were removed. Cells adhering to the lower surface were fixed, stained with Hemacolor ${ }^{\circledR}$ (Merck) and counted.

RNA isolation and reverse transcription. Total cellular RNA was extracted from cells by the RNeasy kit (Qiagen, Hilden, Germany). The integrity of RNA preparations was controlled visually in $1 \%$ agarose/formaldehyde gels. Generation of cDNAs by reverse transcription was performed in $20 \mu \mathrm{l}$ reaction volume containing $2 \mu \mathrm{g}$ of total cellular RNA, $4 \mu \mathrm{l}$ of $5 \mathrm{X}$ first-strand buffer (Invitrogen NV), $2 \mu 1$ of $0.1 \mathrm{M} \mathrm{DTT}, 1 \mu \mathrm{l}$ of dT8TP primer $(10 \mathrm{mM}), 1 \mu \mathrm{l}$ of dNTPs $(10 \mathrm{mM})$ and RNAse-free water. After incubation at $70^{\circ} \mathrm{C}$ for $10 \mathrm{~min}, 1 \mu \mathrm{l}$

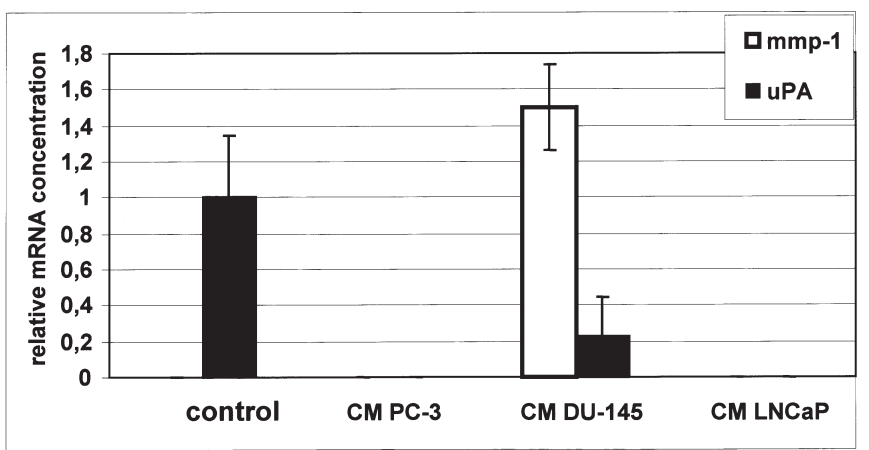

Figure 2. Quantitative RT-PCR analysis of mmp-1 and uPA expression in HFF cells. Expression of mmp-1 and of uPA was determined in HFF cells without stimulation (control) and after stimulation by media conditioned by the three carcinoma cell lines (CM). The mean value of three independent measurements is shown.

of Superscript II reverse transcriptase (Invitrogen NV) was added for the reverse-transcription at $42^{\circ} \mathrm{C}$ for $1 \mathrm{~h}$. The enzyme was inactivated by heating at $70^{\circ} \mathrm{C}$ for $10 \mathrm{~min}$. cDNA quantities were evaluated by comparison to the constitutively expressed ribosomal protein L13A ( $r p \mathrm{~L} 13 \mathrm{~A})$-gene.

Quantitative RT-PCR analysis of MMP-1 and uPA expression. Quantitative real-time RT-PCR was performed on a LightCycler $^{\text {TM }}$ (Roche, Mannheim, Germany) using SybrGreen in combination with RNA-FastStart master kit (Roche). The mixture contained $1 \mu \mathrm{l}$ of cDNA template, $2.4 \mu \mathrm{l} \mathrm{MgCl}_{2}$ $(25 \mathrm{mM}), 0.75 \mu \mathrm{l}$ of each oligonucleotide $(10 \mathrm{mM})$ and $2 \mu 1$ SybrGreen mix in a final volume of $20 \mu \mathrm{l}$. After $5 \mathrm{~min}$ of denaturation, 34 cycles were performed with a denaturation step at $95^{\circ} \mathrm{C}$ for $5 \mathrm{sec}, 20 \mathrm{sec}$ annealing at $56^{\circ} \mathrm{C}$ and $35 \mathrm{sec}$ extension at $72^{\circ} \mathrm{C}$. Oligonucleotides had been synthesized by TIB-Molbiol (Berlin, Germany): RPL13f (5'-TAC GCT GTG AAG GCA TCA AC-3'), RPL13r (5'-CAC CAT CCG CTT TTT CTT GT-3'), MMP1f (5'-GGA CCG ACA ACA ATG AGG AT-3'), MMP1r (5'-TCA AAG GTT CCT GGC AGA AG-3'), uPAf (5'-AGT GCA TGGTGC ATG ACT GC-3'); uPAr (5'-CCA AAG CCA GTG ATC TCA CA-3').

\section{Results}

We stimulated the three prostate cancer cell lines with media which had been conditioned by fibroblasts and the latter with those which had been conditioned by the tumour cells. We then evaluated stimulated and non-stimulated cells for basic cellular functions such as proliferation, invasion and production of proteases involved in matrix degradation. Results are presented first for effects of tumour cell conditioned media on fibroblasts and then for effects of fibroblast conditioned media on tumour cells.

LNCaP, PC-3 and DU-145 cell conditioned media stimulate $H F F$ proliferation. According to current models, the first step of tumour-stroma-interactions at primary or metastatic sites is stroma induction by tumour cell-derived factors. Therefore, we evaluated first the effects of tumour cell conditioned media on fibroblast proliferation. We found HFF proliferation to be 

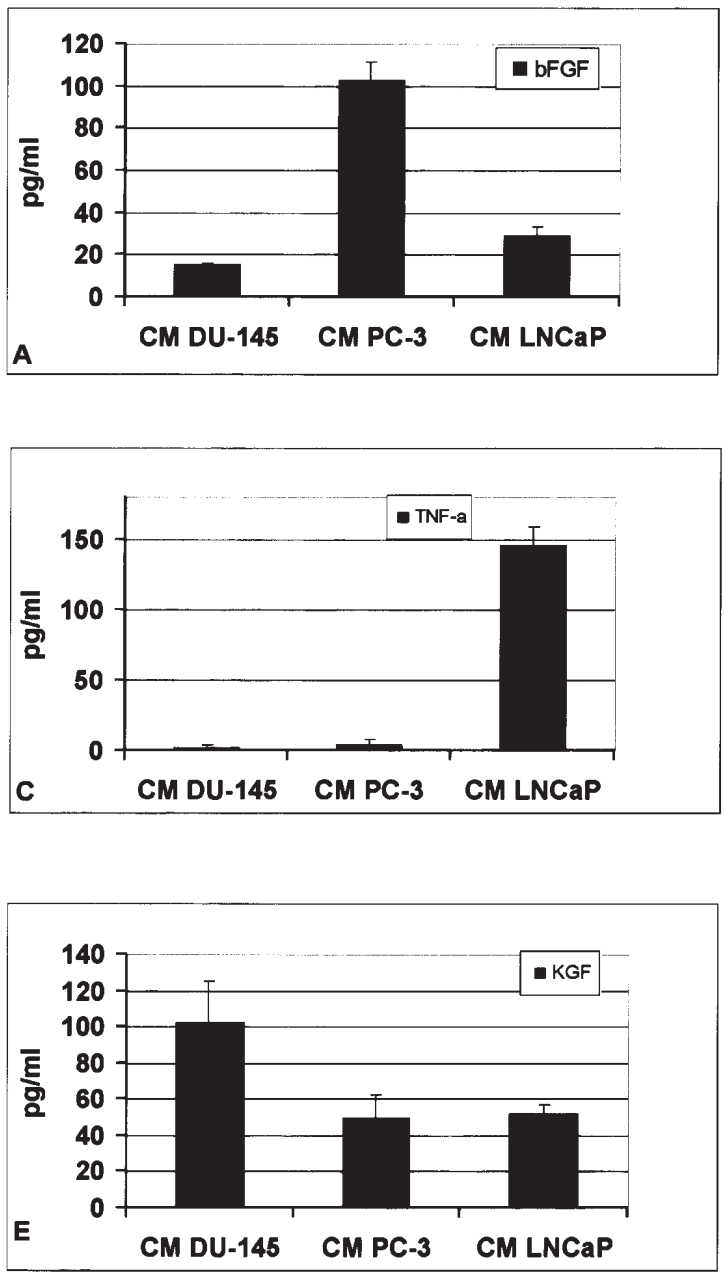
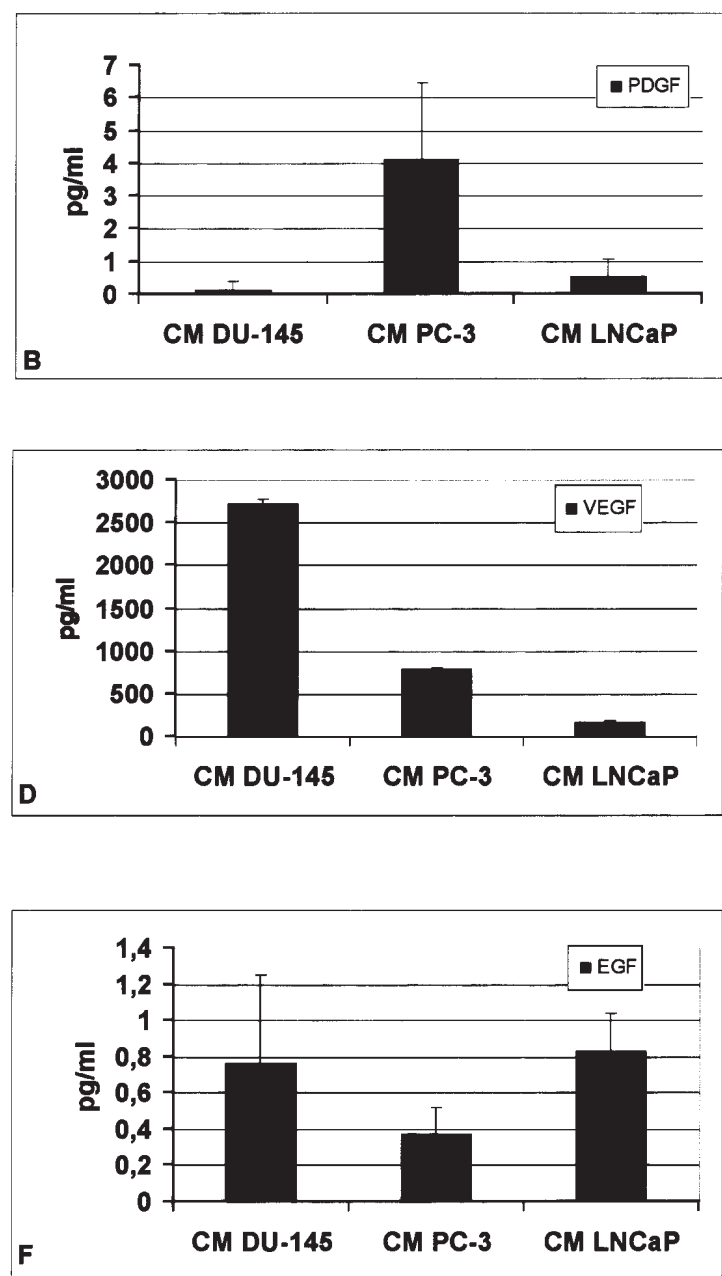

Figure 3. Concentrations of different growth-factors and cytokines in tumour cell conditioned media. Concentrations of bFGF (A), PDGF (B), TNF $\alpha$ (C), VEGF (D), KGF (E) and EGF (F) were determined by ELISA in media conditioned by the three carcinoma cell lines. Cells (2x105) were cultured in $24-$ well plates in $2 \mathrm{ml}$ medium. After $24 \mathrm{~h}$, medium was harvested and concentrations were determined by commercially available ELISAs. The mean value of four independent measurements is shown.

stimulated by media which had been conditioned by all three metastatic prostate carcinoma cell lines (Fig. 1). Stimulation by LNCaP conditioned media augmented proliferation after a lag phase of $24 \mathrm{~h}$ (Fig. 1).

Expression of proteases by HFF. Invasion of tumour cells is another important step during the establishment of metastases. Stroma fibroblasts are suggested to significantly contribute to tumour invasion through a secretion of different matrix-degrading metalloproteinases (MMPs) as well as their activators, such as urokinase-type of plasminogen activator (uPA), which initiates the proteolytic cascade leading to MMP activation. We therefore assessed fibroblasts for expression of MMP1 (an important MMP for invasion) as well as of uPA after stimulation by tumour cell conditioned media.

In quantitative light cycler analyses we found that fibroblasts held in control medium expressed uPA but not mmp-1 transcripts (Fig. 2). Media conditioned by DU-145 cells induced expression of mmp- $1 \mathrm{mRNA}$ in contrast to LNCaP and PC-3 conditioned media. Media which had been conditioned by all 3 cell lines down-regulated uPA mRNA in fibroblasts (Fig. 2).
Determination of growth factors and cytokines secreted by tumour cells. We next determined by ELISA in tumour cell conditioned media the concentrations of several important stroma-inducing or activating growth factors and cytokines known to induce fibroblasts to proliferate and/or to express matrix-degrading proteases such as MMP-1 and uPA according to our previous findings (56). Results are shown in Fig. 3.

We found that bFGF, PDGF and TNF $\alpha$ which stimulate fibroblast proliferation and/or induce MMP-1 and UPA in HFF are actually secreted at different concentrations by the metastatic prostate cancer cell lines. Both bFGF and PDGF were secreted at highest amounts by PC-3 cells followed by LNCaP and DU-145 cells. TNF $\alpha$ concentration was highest in LNCaP conditioned media. In contrast TNF $\alpha$ was barely detectable in media conditioned by PC-3 and DU- 145 cells.

VEGF is considered the most important angiogenic factor for tumour vascularization which is the prerequisite for continuous tumour growth at primary or metastatic sites. This factor was secreted at the highest amounts by DU-145 cells followed by PC-3 and LNCaP cells (Fig. 3D).

All three tumour cell lines also secreted KGF and EGF known to stimulate proliferation of prostatic epithelial cells 


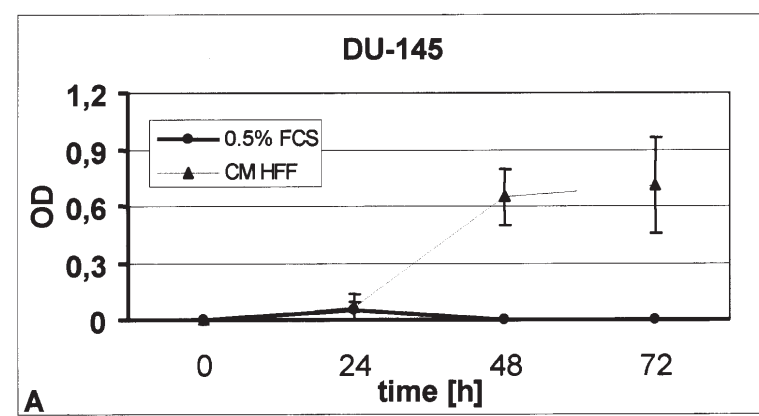

Day 28

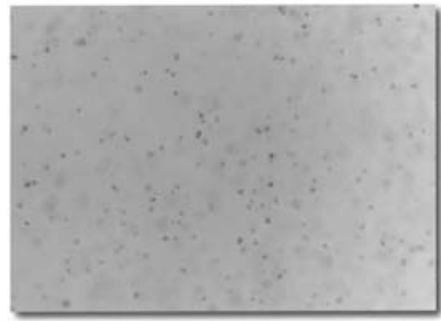

$0.5 \% \mathrm{FCS}$

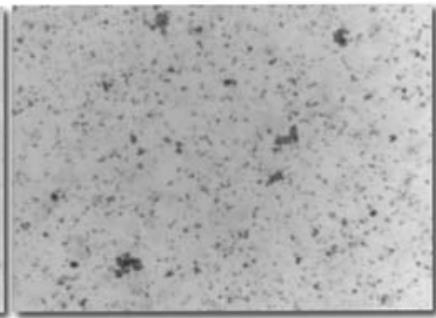

HFF CM
Figure 5. Fibroblast conditioned medium (FCM) increases soft agar growth of DU-145 cells. When anchorage-independent growth of the three prostate carcinoma cell lines was analysed in soft-agar, Du-145 cells showed an increased growth after treatment with fibroblast conditioned medium compared to the starvation medium. Results are shown for day 28 . In contrast, fibroblast conditioned medium had no influence on anchorageindependent growth of LNCaP and PC-3 cells

(57). We next assessed diverse effects of fibroblast conditioned media on the three metastatic prostate cancer cell lines.

Effects of fibroblast conditioned media on proliferation of prostate carcinoma cell lines. We cultivated the 3 carcinoma cell lines in media which had been conditioned by fibroblasts for $24 \mathrm{~h}$ and used tumour cell lines starved in medium with $0.5 \%$ FCS as negative controls. Results are shown in Fig. 4.

Cultivation of DU-145 carcinoma cells in fibroblast conditioned medium resulted in an enhanced proliferation at all investigated time points compared to the control (Fig. 4A). In the case of PC-3 cells measurements after 24 and $48 \mathrm{~h}$ shown.
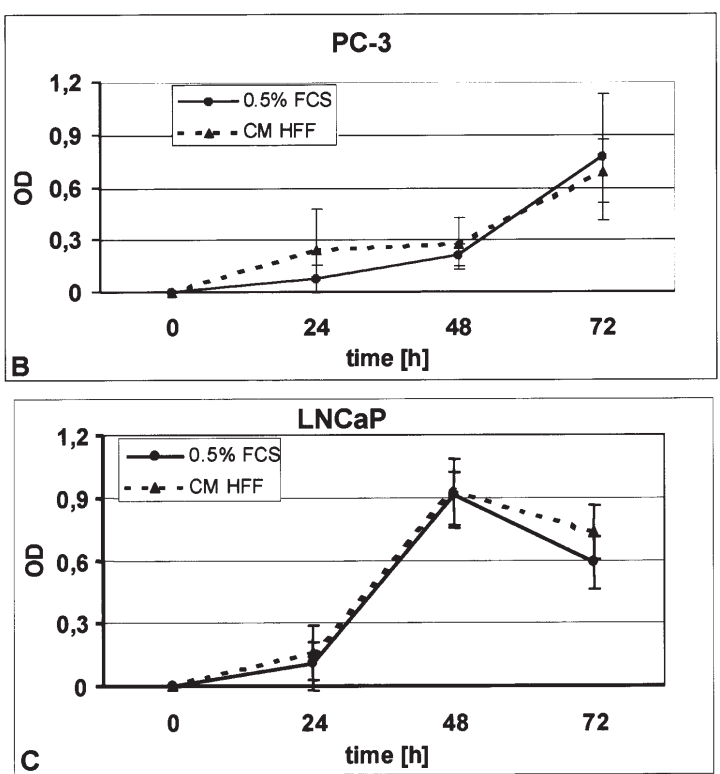

Figure 4. Proliferation of prostate carcinoma cell lines in fibroblast conditioned or starvation media. Proliferation of DU-145 (A), PC-3 (B) and LNCaP cells (C) was determined in starvation medium $\left(0.5 \%\right.$ FCS) and HFF conditioned medium (CM HFF) by a modified MTT-test. Cells (2x10 $\left.{ }^{3}\right)$ were cultured in 96-well plates in $200 \mu 1$ medium. Stimulation by fibroblast conditioned media was performed for 24 h. The mean value of five independent measurements is

\section{$\mathrm{PC}-3+\mathrm{HFF}-\mathrm{CM}$}

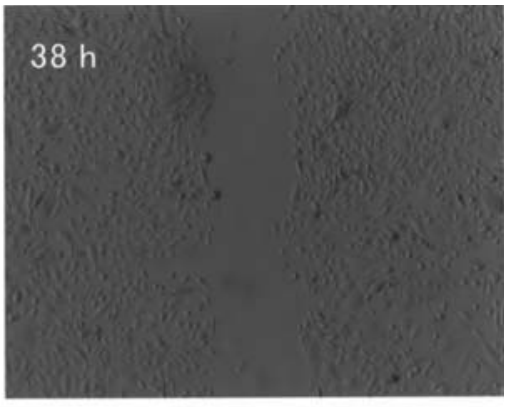

$38 \mathrm{~h}$

Figure 6. Fibroblast conditioned medium (FCM) increases migration of PC-3 prostate carcinoma cells in the wound assay. Monolayers of confluent cultures of all three tumour cell lines were lightly scratched with a pipet tip. Detached cells were removed by washing and the cultures were incubated with either fibroblast conditioned or control media. Fibroblast conditioned media increased migration of PC-3 cells after 28 and $38 \mathrm{~h}$ of incubation. Migration of the two other tumour cell lines was not changed (data not shown).

demonstrated a slightly increased proliferation in fibroblast conditioned media (Fig. 4B). However, these differences were not significant $(\mathrm{p}=0.242)$. LNCaP cells had a comparable proliferation rate in control medium and in $\mathrm{HFF}$ conditioned medium (Fig. 4C). 

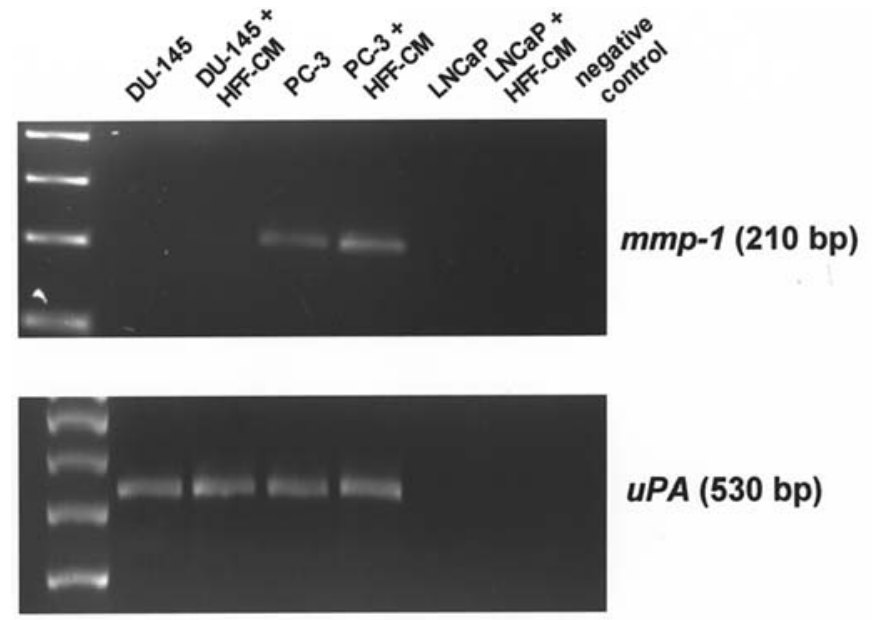

uPA (530 bp)

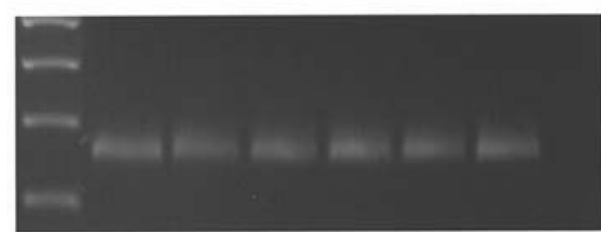

RPL13A (251 bp)

\section{M}

Figure 7. RT-PCR analysis of $m m p-1$ and $u P A$ expression in prostate carcinoma cell lines. RT-PCR for $m m p-1, u P A$ and RPL13A was performed with RNA isolated from DU-145, PC-3 and LNCaP cells after incubation in either control media or HFF conditioned media. Size of amplification products were $210 \mathrm{bp}$ for $m m p-1,530 \mathrm{bp}$ for $u P A$ and $251 \mathrm{bp}$ for RPL13A. Transcripts of $m m p-1$ and $u P A$ were detected in PC-3 cells and transcripts of $u P A$ in DU-145 cells. None of these transcripts were found in LNCaP cells. After incubation in fibroblast conditioned media the amount of mmp-1 transcripts in PC-3 cells increased slightly. The amount of $u P A$ transcripts in PC-3 and DU-145 cells was not affected by incubation in HFF conditioned media.

Anchorage-independent growth of prostate carcinoma cell lines in soft agar assay. One significant feature of cancer cell lines is the ability to grow in an anchorage-independent way. Therefore, the three prostate carcinoma cell lines were analyzed under different growth conditions in soft agar. Again, the growth of cell lines incubated in medium with $0.5 \%$ FCS was used as an internal control. Du-145 cells showed an increased growth after treatment with fibroblast conditioned medium (Fig. 5). In contrast, fibroblast conditioned medium had no influence on the growth of LNCaP and PC-3 cells.

Effect of fibroblast conditioned media on prostate cancer cell migration and invasion. Cell migration and invasion are important features of tumour progression. Using the wound assay we found that fibroblast conditioned medium increased migration of PC-3 cells after 28 and 38 h (Fig. 6). In contrast, no clear effect was evident on migration of DU-145 and LNCaP cells. Fibroblast conditioned media had no effects on the invasive behaviour of the three cancer cell lines in the Boyden Chamber assay (data not shown).

Expression of proteases by prostate carcinoma cells. We also analyzed whether proteases are induced by fibroblast conditioned media in tumour cell lines. We first assessed expression of proteases in tumour cells in control media. We detected transcripts of $m m p-1$ and $u P A$ in PC-3 cells and
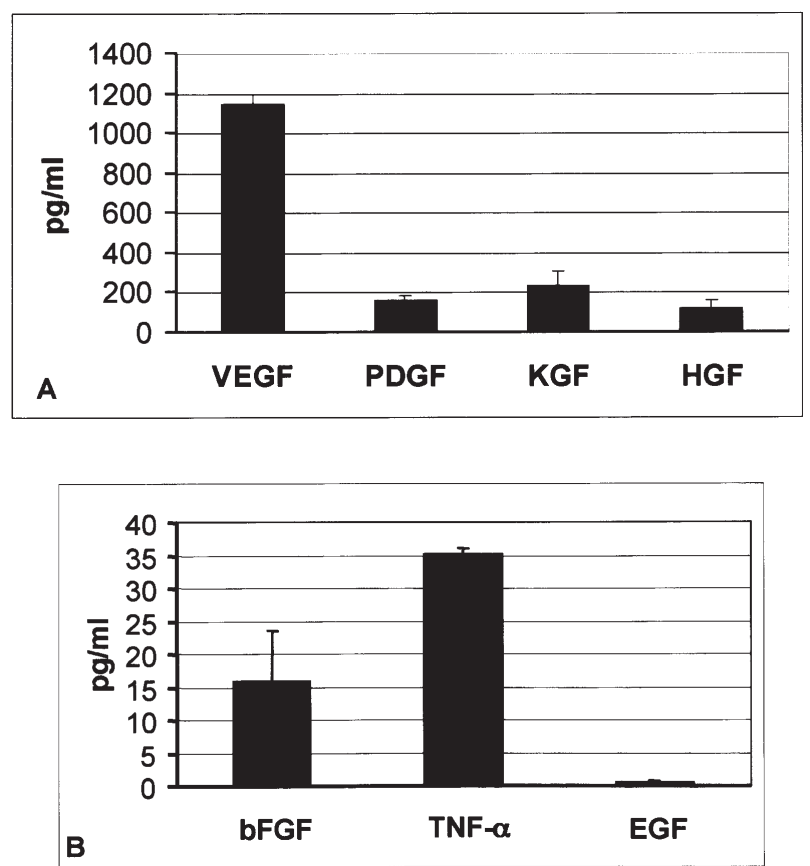

Figure 8. Concentrations of different growth-factors and cytokines in fibroblast (HFF) conditioned medium. Concentrations of VEGF, PDGF, KGF, HGF (A), bFGF, TNF $\alpha$ and EGF (B) were determined by ELISA in media conditioned by the HFF cell line (HFF-CM). Cells $\left(2 \times 10^{5}\right)$ were cultured in 24-well plates in $2 \mathrm{ml}$ medium. After $24 \mathrm{~h}$, medium was harvested and concentrations were determined by commercially available ELISAs. The mean value of four independent determinations is shown. KGF was secreted by fibroblasts at higher concentrations than by all three tumour cell lines. VEGF was secreted at higher amounts than by PC-3 and LNCaP cells (compare to Fig. 3).

transcripts of $u P A$ in DU-145 cells. None of these transcripts were detected in LNCaP cells. After incubation in fibroblast conditioned media the amount of $m m p-1$ transcripts in PC-3 cells increased slightly (Fig. 7). In contrast the amount of $u P A$ in PC-3 and DU-145 cells was not affected by incubation in fibroblast conditioned media (Fig. 7).

Determination of growth factors and cytokines secreted by fibroblasts. We next determined by ELISA the concentrations of different growth factors and cytokines secreted by fibroblasts into the conditioned media. Results are shown in Fig. 8. We found KGF to be secreted by fibroblasts at higher concentrations than by all three tumour cell lines. In addition, fibroblasts secreted TNF $\alpha, b F G F$, PDGF, HGF and VEGF. The latter was secreted at higher amounts by fibroblasts than by PC-3 and LNCaP cell lines.

\section{Discussion}

Previous work on tumour stroma interactions in the prostate has largely focused on the primary site $(27,36)$. In the present study, we searched evidence for a cross-talk between metastatic prostate cancer cell lines and non-prostatic fibroblasts which are encountered by prostate cancer cells at different metastatic sites. We tried to characterize some functional interactions between tumour cells and fibroblasts, and to decipher messages exchanged between them in terms of secreted growth factors and cytokines. 
Since dynamic interactions can hardly be deciphered in vivo we addressed these issues in cell culture systems. We used three established metastatic human prostate cancer cell lines on the one hand, and a human fibroblast line on the other which we had well characterized in previous studies $(56,58)$. Cell isolation from fresh prostate tissues is possible $(59,60)$ but has inherent problems such as preparation of 'pure' cell populations and short life-span of primary cells. In addition, the genetic background of different patients renders data difficult to interpret and to compare.

During metastatic progression prostate cancer cells have to pass through each step of the so-called metastatic cascade including proliferation, vascularization and invasion. Our results provide evidence that interactions between metastatic prostate cancer cells and fibroblasts have effects on several of these steps. For continuous growth and propagation at metastatic sites tumour cells first have to induce a supportive stroma. We found that media conditioned by all three metastatic prostate cancer cell lines are capable of inducing cultured fibroblasts to proliferate which corresponds to fibrous stroma induction in vivo. Degree and kinetics of proliferation differed, however, between media conditioned by the three cancer cell lines which is in line with the known fact that induction of fibroblastic stroma can differ between different tumours. We also identified in prostate cancer cell conditioned media growth factors (such as bFGF and PDGF) to which induction of fibroblast proliferation can be attributed $(61,62)$. Basic fibroblast growth factor is already known to induce stromal growth within the human prostate (63). In the present study, both bFGF and PDGF were secreted at the highest amounts by PC-3 cells followed by LNCaP and DU-145 cells which did not reflect exactly the effects of tumour cell conditioned media on fibroblast proliferation. However, we did not display the whole 'secretome' $(64,65)$ of the three tumour cells and these cells certainly secrete more factors than those determined in our study. We further found that not only tumour cells but also fibroblasts secrete bFGF and PDGF in line with additional autocrine effects of these factors on fibroblast proliferation.

Tumour cell proliferation is an essential step for metastasis formation and we found that fibroblasts in turn also stimulated proliferation of the DU-145 metastatic prostate cancer cell line while showing no significant effects on proliferation of the two other cell lines. This was well in line with an increase of anchorage-independent growth of DU-145 cells in soft agar assays after stimulation with fibroblast conditioned medium. In ELISA assays of fibroblast conditioned media we identified KGF as a known factor able to stimulate proliferation of normal and neoplastic prostate epithelial cells (66). The fact that all three metastatic prostate cancer cell lines secreted KGF similarly suggests again an autocrine effect on tumour cell proliferation.

Tumour cell proliferation alone is not sufficient for continuous growth of metastases which also requires tumour vascularization $(30,56,67-70)$. VEGF is considered the most important factor for tumour vascularization (71). This factor was secreted at the highest amounts by DU-145 cells followed by PC-3 and LNCaP cells. Interestingly, we found that, besides the metastatic prostate cancer cells, fibroblasts also secrete VEGF. This suggests that both neoplastic and stromal cells can induce tumour vascularization in prostate cancer metastases through VEGF secretion. VEGF A is not only the most potent angiogenic factor, but is also thought to participate in the formation of fibroblastic stroma via a pronounced hyperpermeability effect on small blood vessels, leading to fibrin leakage with subsequent organization by granulation tissue which turns into fibroblastic connective tissue $(72,73)$. Moreover, an autocrine function of VEGF on prostate cancer cell proliferation has been suggested by the demonstration of the high affinity receptors VEGFR-1 and VEGFR-2 on prostate cancer cells $(74,75)$. VEGFR-1 has been found to be slightly expressed in PC-3 but not expressed in LNCaP and DU-145 cells (76).

Cell migration is an important part of tumour cell invasion at metastatic sites. Using the wound assay we found that fibroblast conditioned medium increased migration of PC-3 cells (77).

It has been shown in recent years that stromal fibroblasts participate in a major way in tumour invasion by secreting various matrix-degrading proteases $(30,78)$, as well as their downstream activators such as uPA (31). Proteases carry out balanced degradation of extracellular matrix components facilitating tumour invasion (56,79-82). In quantitative light cycler analyses we found that media conditioned by DU-145 cells induced in fibroblasts expression of mmp- 1 mRNA in contrast to LNCaP and PC-3 conditioned media. According to our previous findings bFGF, PDGF and TNF $\alpha$ are capable of inducing mmp-1 in the used fibroblast line probably via an activation of the Ets-1 transcription factor (56). However, these factors are secreted at only very low concentrations by DU-145 cells suggesting that other factors are responsible for mmp-1 induction in fibroblasts.

MMPs not only promote tumour invasion through matrix degradation but also release growth factors, angiogenic factors, and their inhibitors from the ECM and cell surfaces $(83,84)$ thereby regulating bioavailability of growth factors. MMP-1 has been described to degrade perlecan and release bound FGF (85).

In vivo, cross-talk between metastatic prostate cancer cells and their stromal microenvironment includes more interactions than those demonstrated in this study. More than just tumour cells and fibroblasts are present in the microenvironment of metastatic sites including inflammatory, immune-competent cells and macrophages all of which participate in multidirectional communications (reviewed in ref. 30). Moreover, stroma tumour cell interactions probably also exhibit differences at different sites and finally functional properties of fibroblasts may be different at different metastatic sites.

However, the results of this study provide evidence that intercellular communications exist not only at the primary site but also between metastatic prostate cancer cell lines and their fibroblastic microenvironment. These interactions affect several steps of the metastatic cascade. Our results also suggest that the way and results of tumour-stroma communications differ according to particular features of metastatic tumour cell clones. This concerns particularly concentrations of growth factors and cytokines secreted by the neoplastic cells. Effects of different spectra of factors are probably not just the sum of effects of single factors but rather the result of nonlinear potentiations or inhibitions. 


\section{Acknowledgements}

This work was supported by a grant from the German Cancer Association ('Deutsche Krebshilfe' Grant No. 10-1877-We 2) and the German Research Association (Deutsche Forschungsgemeinschaft, DFG, Grant No. WE 1104/8-1; WE 1104/8-2).

\section{References}

1. Denmeade SR and Isaacs JT: A history of prostate cancer treatment. Nat Rev Cancer 2: 389-396, 2002.

2. Visakorpi T, Hyytinen E, Koivisto P, Tanner M, Keinanen R, Palmberg C, Palotie A, Tammela T, Isola J and Kallioniemi OP: In vivo amplification of the androgen receptor gene and progression of human prostate cancer. Nat Genet 9: 401-406, 1995.

3. McKenna NJ and O'Malley BW: Nuclear receptor coactivators an update. Endocrinology 143: 2461-2465, 2001.

4. Giovannucci E: Nutritional factors in human cancers. Adv Exp Med Biol 472: 29-42, 1999.

5. Jankevicius F, Miller SM and Ackermann R: Nutrition and risk of prostate cancer. Urol Int 68: 69-80, 2002.

6. Bratt O: Hereditary prostate cancer: clinical aspects. J Urol 168: 906-913, 2002.

7. Simard J, Dumont M, Soucy P and Labrie F: Prostate cancer susceptibility genes. Endocrinology 143: 2029-2040, 2002.

8. Ingles SA, Ross RK, Yu MC, Irvine RA, La Pera G, Haile RW and Coetzee GA: Association of prostate cancer risk with genetic polymorphisms in vitamin $\mathrm{D}$ receptor and androgen receptor. J Natl Cancer Inst 89: 166-170, 1997.

9. Steinhoff C, Franke KH, Golka K, Thier R, Romer HC, Rotzel C, Ackermann R and Schulz WA: Glutathione transferase isozyme genotypes in patients with prostate and bladder carcinoma. Arch Toxicol 74: 521-526, 2000.

10. Jenkins RB, Qian J, Lieber MM and Bostwick DG: Detection of c-myc oncogene amplification and chromosomal anomalies in metastatic prostatic carcinoma by fluorescence in situ hybridization. Cancer Res 57: 524-531, 1997.

11. Saramaki O, Willi N, Bratt O, Gasser TC, Koivisto P, Nupponen NN, Bubendorf L and Visakorpi T: Amplification of EIF3S3 gene is associated with advanced stage in prostate cancer. Am J Pathol 159: 2089-2094, 2001.

12. McDonnell TJ, Troncoso P, Brisbay SM, Logothetis C, Chung LW, Hsieh JT, Tu SM and Campbell ML: Expression of the protooncogene bcl-2 in the prostate and its association with emergence of androgen-independent prostate cancer. Cancer Res 52: 6940-6944, 1992.

13. Djakiew D: Dysregulated expression of growth factors and their receptors in the development of prostate cancer. Prostate 42 : $150-160,2000$.

14. Navone NM, Troncoso P, Pisters LL, Goodrow TL, Palmer JL, Nichols WW, von Eschenbach AC and Conti CJ: p53 protein accumulation and gene mutation in the progression of human prostate carcinoma. J Natl Cancer Inst 85: 1657-1669, 1993.

15. Li J, Yen C, Liaw D, Podsypanina K, Bose S, Wang SI, Puc J, Miliaresis C, Rodgers L, McCombie R, Giovanella BC, Bigner SH, Ittmann M, Tycko B, Hibshoosh H, Wigler MH and Parsons R: PTEN, a putative protein tyrosine phosphatase gene mutated in human brain, breast, and prostate cancer. Science 275: 1943-1947, 1997.

16. Hügel A and Wernert N: Loss of heterozygosity, malignancy grade and clonality in microdissected prostate cancer. $\mathrm{Br} \mathbf{J}$ Cancer 79: 551-557, 1999.

17. Lijovic M and Frauman AG: Toward an understanding of the molecular genetics of prostate cancer progression. J Environ Pathol Toxicol Oncol 22: 1-15, 2003.

18. Banham AH, Beasley N, Campo E, Fernandez PL, Fidler C, Gatter K, Jones M, Mason DY, Prime JE, Trougouboff P, Wood K and Cordell JL: The FOXP1 winged helix transcription factor is a novel candidate tumor suppressor gene on chromosome 3p. Cancer Res 61: 8820-8829, 2001

19. Kuzmin I, Gillespie JW, Protopopov A, Geil L, Dreijerink K, Yang Y, Vocke CD, Duh FM, Zabarovsky E, Minna JD, Rhim JS, Emmert-Buck MR, Linehan WM and Lerman MI: The RASSF1A tumor suppressor gene is inactivated in prostate tumors and suppresses growth of prostate carcinoma cells. Cancer Res 62: 3498-3502, 2002.
20. Srivastava M, Bubendorf L, Srikantan V, Fossom L, Nolan L, Glasman M, Leighton X, Fehrle W, Pittaluga S, Raffeld M, Koivisto P, Willi N, Gasser TC, Kononen J, Sauter G, Kallioniemi OP, Srivastava S and Pollard HB: ANX7, a candidate tumor suppressor gene for prostate cancer. Proc Natl Acad Sci USA 98: 4575-4580, 2001.

21. Dong JT: Chromosomal deletions and tumor suppressor genes in prostate cancer. Cancer Metastasis Rev 20: 173-193, 2001 .

22. Adorjan P, Distler J, Lipscher E, Model F, Muller J, Pelet C, Braun A, Florl AR, Gutig D, Grabs G, Howe A, Kursar M, Lesche R, Leu E, Lewin A, Maier S, Muller V, Otto T, Scholz C, Schulz WA, Seifert HH, Schwope I, Ziebarth H, Berlin K, Piepenbrock $\mathrm{C}$ and Olek $\mathrm{A}$ : Tumour class prediction and discovery by microarray-based DNA methylation analysis. Nucleic Ácids Res 30: E21, 2002.

23. Maruyama R, Toyooka S, Toyooka KO, Virmani AK, Zochbauer-Muller S, Farinas AJ, Minna JD, McConnell J, Frenkel EP and Gazdar AF: Aberrant promoter methylation profile of prostate cancers and its relationship to clinicopathological features. Clin Cancer Res 8: 514-519, 2002.

24. Schulz WA, Elo JP, Florl AR, Pennanen S, Santourlidis S, Engers R, Buchardt M, Seifert HH and Visakorpi T: Genomewide DNA hypomethylation is associated with alterations on chromosome 8 in prostate carcinoma. Genes Chromosomes Cancer 35: 58-65, 2002.

25. Gerstein AV, Almeida TA, Zhao G, Chess E, Shih M, Buhler K, Pienta K, Rubin MA, Vessella R and Papadopoulos N: APC/ CTNNB1 (beta-catenin) pathway alterations in human prostate cancers. Genes Chromosomes Cancer 34: 9-16, 2002.

26. Ko Y, Hahn T, Lu H, Ma ZL, Chen J, Rothe M, Florin A, Fronhoffs S, Albers P, Sachinidis A, Vetter H, Kaminski A, Behrens P, Wellmann A and Wernert N: A novel component of the ubiquitin pathway, ubiquitin carboxyl extension protein 1 is overexpressed in prostate cancer. Int J Mol Med 15: 183-196, 2005.

27. Cunha GR, Hayward SW and Wang YZ: Role of stroma in carcinogenesis of the prostate. Differentiation 70: 473-485, 2002.

28. Sung SY and Chung LW: Prostate tumor-stroma interaction: molecular mechanisms and opportunities for therapeutic targeting. Differentiation 70: 506-521, 2002.

29. Wernert N, Locherbach C, Wellmann A, Behrens P and Hugel A: Presence of genetic alterations in microdissected stroma of human colon and breast cancers. Anticancer Res 21: 2259-2264, 2001 .

30. Wernert N: The multiple roles of tumour stroma. Virch Arch A 430: 433-443, 1997.

31. Liotta LA and Kohn EC: The microenvironment of the tumourhost interface. Nature 411: 375-379, 2001

32. Cunha GR: Role of mesenchymal-epithelial interactions in normal and abnormal development of the mammary gland and prostate. Cancer 74: 1030-1044, 1994.

33. Cunha GR: Growth factors as mediators of androgen action during male urogenital development. Prostate (Suppl 6): 22-25, 1996.

34. Cunha GR, Hayward SW, Dahiya R and Foster BA: Smooth muscle-epithelial interactions in normal and neoplastic prostatic development. Acta Anat (Basel) 155: 63-72, 1996.

35. Hayward SW, Haughney PC, Rosen MA, Greulich KM, Weier HU, Dahiya R and Cunha GR: Interactions between adult human prostatic epithelium and rat urogenital sinus mesenchyme in a tissue recombination model. Differentiation 63: 131-140, 1998.

36. Hayward SW, Rosen MA and Cunha GR: Stromal-epithelial interactions in the normal and neoplastic prostate. Br J Urol 79: 18-26, 1997.

37. Chung LW and Davies R: Prostate epithelial differentiation is dictated by its surrounding stroma. Mol Biol Rep 23: 13-19, 1996.

38. Condon MS and Bosland MC: The role of stromal cells in prostate cancer development and progression. In Vivo 13: 61-65, 1999.

39. Kooistra A, Romijn JC and Schroder FH: Stromal inhibition of epithelial cell growth in the prostate; overview of an experimental study. Urol Res 25 (Suppl 2): S97-S105, 1997.

40. Camps JL, Chang SM, Hsu TC, Freeman MR, Hong SJ, Zhau HE, von Eschenbach AC and Chung LW: Fibroblast mediated acceleration of human epithelial tumor growth in vivo. Proc Natl Acad Sci USA 87: 75-79, 1990. 
41. Olumi AF, Dazin P and Tlsty TD: A novel coculture technique demonstrates that normal human prostatic fibroblasts contribute to tumor formation of $\mathrm{LNCaP}$ cells by retarding cell death. Cancer Res 58: 4525-4530, 1998.

42. Wellmann A, Wollscheid V, Lu H, Ma ZL, Albers P, Schutze K, Rohde V, Behrens P, Dreschers S, Ko Y and Wernert N: Analysis of microdissected prostate tissue with ProteinChip arrays - a way to new insights into carcinogenesis and to diagnostic tools. Int J Mol Med 9: 341-347, 2002.

43. Schmidt U, Bilkenroth U, Linne C, Fuessel S, Kraemer K, Froehner M, Wirth MP and Meye A: Quantification of disseminated tumor cells in the bloodstream of patients with hormone-refractory prostate carcinoma undergoing cytotoxic chemotherapy. Int J Oncol 24: 1393-1399, 2004

44. Straub B, Muller M, Krause H, Schrader M and Miller K: Quantitative real-time rt-PCR for detection of circulating prostate-specific antigen mRNA using sequence-specific oligonucleotide hybridization probes in prostate cancer patients. Oncology 65 (Suppl 1): 12-17, 2003.

45. Rubin MA, Putzi M, Mucci N, Smith DC, Wojno K, Korenchuk S and Pienta KJ: Rapid 'warm' autopsy study for procurement of metastatic prostate cancer. Clin Cancer Res 6: 1038-1045, 2000.

46. Rubin MA, Gerstein A, Reid K, Bostwick DG, Cheng L, Parsons R and Papadopoulos N: 10q23.3 loss of heterozygosity is higher in lymph node-positive $\left(\mathrm{pT} 2-3, \mathrm{~N}^{+}\right)$versus lymph nodenegative (pT2-3,N0) prostate cancer. Hum Pathol 31: 504-508, 2000.

47. Bubendorf L, Schopfer A, Wagner U, Sauter G, Moch H, Willi N, Gasser TC and Mihatsch MJ: Metastatic patterns of prostate cancer: an autopsy study of 1,589 patients. Hum Pathol 31: 578-583, 2000.

48. Lehr JE and Pienta KJ: Preferential adhesion of prostate cancer cells to a human bone marrow endothelial cell line. J Natl Cancer Inst 90: 118-123, 1998.

49. Cooper CR, McLean L, Walsh M, Taylor J, Hayasaka S, Bhatia J and Pienta KJ: Preferential adhesion of prostate cancer cells to bone is mediated by binding to bone marrow endothelial cells as compared to extracellular matrix components in vitro. Clin Cancer Res 6: 4839-4847, 2000.

50. Chay CH, Cooper CR, Gendernalik JD, Dhanasekaran SM, Chinnaiyan AM, Rubin MA, Schmaier AH and Pienta KJ: A functional thrombin receptor (PAR1) is expressed on bone-derived prostate cancer cell lines. Urology 60: 760-765, 2002.

51. Wernert N, Okuducu AF and Pepper MS: Ets 1 is expressed in capillary blood vessels but not in lymphatics. J Pathol 200: 561-567, 2003

52. Mandriota SJ, Jussila L, Jeltsch M, Compagni A, Baetens D, Prevo R, Banerji S, Huarte J, Montesano R, Jackson DG, Orci L, Alitalo K, Christofori G and Pepper MS: Vascular endothelial growth factor-C-mediated lymphangiogenesis promotes tumour metastasis. EMBO J 20: 672-682, 2001.

53. Horoszewicz JS, Leong SS, Chu TM, Wajsman ZL, Friedman M, Papsidero L, Kim U, Chai LS, Kakati S, Arya SK and Sandberg AA: The LNCaP cell line - a new model for studies on human prostatic carcinoma. Prog Clin Biol Res 37: 115-132, 1980.

54. Stone KR, Mickey DD, Wunderli H, Mickey GH and Paulson DF: Isolation of a human prostate carcinoma cell line (DU 145). Int J Cancer 21: 274-281, 1978.

55. Kaighn ME, Narayan KS, Ohnuki Y, Lechner JF and Jones LW: Establishment and characterization of a human prostatic carcinoma cell line (PC-3). Invest Urol 17: 16-23, 1979.

56. Wernert N, Gilles F, Fafeur V, Bouali F, Raes MB, Pyke C, Dupressoir T, Seitz G, Vandenbunder B and Stéhelin D: Stromal expression of c-ets 1 transcription factor correlates with tumor invasion. Cancer Res 54: 5683-5688, 1994.

57. Peehl DM, Wong ST and Rubin JS: KGF and EGF differentially regulate the phenotype of prostatic epithelial cells. Growth Regul 6: 22-31, 1996

58. Gilles F, Raes MB, Stéhelin D, Vandenbunder B and Fafeur V: The c-ets- 1 proto-oncogene is a new early response gene differentially regulated by cytokines and growth factors in human fibroblasts. Exp Cell Res 222: 370-378, 1996.

59. Zwergel T, Kakirman H, Rohde V, Wullich B and Unteregger G: Androgen receptor expression, proliferation index and aneuploidy in tissue explant cultures derived prostate carcinoma cells co-cultivated on membranes. Eur Urol 33: 414-423, 1998.
60. Ketter R, Zwergel T, Romanakis K, Unteregger G, Ziegler M, Zang KD and Wullich B: Selection toward diploid cells in prostatic carcinoma derived cell cultures. Prostate 28: 364-371, 1996.

61. Denk PO, Hoppe J, Hoppe V and Knorr M: Effect of growth factors on the activation of human Tenon's capsule fibroblasts. Curr Eye Res 27: 35-44, 2003.

62. Takahashi S, Nakajima M, Kobayashi M, Wakabayashi I, Miyakoshi N, Minagawa $\mathrm{H}$ and Itoi E: Effect of recombinant basic fibroblast growth factor (bFGF) on fibroblast-like cells from human rotator cuff tendon. Tohoku J Exp Med 198: 207-214, 2002.

63. Sherwood ER, Fong CJ, Lee C and Kozlowski JM: Basic fibroblast growth factor: a potential mediator of stromal growth in the human prostate. Endocrinology 130: 2955-2963, 1992.

64. Klee EW, Carlson DF, Fahrenkrug SC, Ekker SC and Ellis LB: Identifying secretomes in people, pufferfish and pigs. Nucleic Acids Res 32: 1414-1421, 2004.

65. Dupont A, Tokarski C, Dekeyzer O, Guihot AL, Amouyel P, Rolando $\mathrm{C}$ and Pinet F: Two-dimensional maps and databases of the human macrophage proteome and secretome. Proteomics 4: 1761-1778, 2004

66. Ropiquet F, Huguenin S, Villette JM, Ronfle V, Le Brun G, Maitland NJ, Cussenot O, Fiet J and Berthon P: FGF7/KGF triggers cell transformation and invasion on immortalised human prostatic epithelial PNT1A cells. Int J Cancer 82: 237-243, 1999.

67. Rothhammer T, Hahne JC, Florin A, Poser I, Soncin F, Wernert N and Bosserhoff AK: The Ets-1 transcription factor is involved in the development and invasion of malignant melanoma. Cell Mol Life Sci 61: 118-128, 2004

68. Sharrocks AD, Brown AL, Ling Y and Yates PR: The ETSdomain transcription factor family. Int J Biochem Cell Biol 29: 1371-1387, 1997

69. Wernert N, Raes MB, Lasalle P, Gosselin B, Vandenbunder B and Stéhelin D: The c-ets 1 proto-oncogene is a transcription factor expressed in endothelial cells during tumor vascularization and other forms of angiogenesis in man. Am J Pathol 140: 119-127, 1992

70. Wernert N, Stanjek A, Kiriakidis S, Hügel A, Jha HC, Mazitschek R and Giannis A: Inhibition of in vivo angiogenesis by ets-1 antisense oligonucleotides - Inhibition of Ets-1 transcription factor expression by the antibiotic fumagillin. Angew Chem Int Ed Engl 38: 3228-3231, 1999.

71. Ferrara N: The role of VEGF in the regulation of physiological and pathological angiogenesis. EXS 94: 209-231, 2005.

72. Dvorak HF: Rous-Whipple Award Lecture. How tumors make bad blood vessels and stroma. Am J Pathol 162: 1747-1757, 2003.

73. Dvorak HF, Brown LF, Detmar M and Dvorak AM: Vascular permeability factor/vascular endothelial growth factor, microvascular hyperpermeability, and angiogenesis. Am J Pathol 146: 1029-1039, 1995.

74. Jackson MW, Roberts JS, Heckford SE, Ricciardelli C, Stahl J, Choong C, Horsfall DJ and Tilley WD: A potential autocrine role for vascular endothelial growth factor in prostate cancer. Cancer Res 62: 854-859, 2002.

75. Ferrer FA, Miller LJ, Lindquist R, Kowalczyk P, Laudone VP, Albertsen PC and Kreutzer DL: Expression of vascular endothelial growth factor receptors in human prostate cancer. Urology 54: 567-572, 1999.

76. Yamada Y, Watanabe M, Yamanaka M, Hirokawa Y, Suzuki H, Takagi A, Matsuzaki T, Sugimura Y, Yatani R and Shiraishi T: Aberrant methylation of the vascular endothelial growth factor receptor-1 gene in prostate cancer. Cancer Sci 94: 536-539, 2003.

77. Wong AS, Leung PC and Auersperg N: Hepatocyte growth factor promotes in vitro scattering and morphogenesis of human cervical carcinoma cells. Gynecol Oncol 78: 158-165, 2000.

78. Sreenath T, Matrisian LM, Stetler-Stevenson W, Gattoni-Celli S and Pozzatti RO: Expression of matrix metalloproteinase genes in transformed rat cell lines of high and low metastatic potential. Cancer Res 52: 4942-4947, 1992.

79. Pyke C, Ralfkiær E, Tryggvason K and Danø K: Messenger RNA for two type IV collagenases is located in stromal cells in human colon cancer. Am J Pathol 142: 359-365, 1993.

80. Behrens P, Rothe M, Wellmann A, Krischler J and Wernert N: The Ets-1 transcription factor is up-regulated together with MMP 1 and MMP 9 in the stroma of pre-invasive breast cancer. J Pathol 194: 43-50, 2001. 
81. Behrens P, Rothe M, Florin A, Wellmann A and Wernert N: Invasive properties of serous human epithelial ovarian tumors are related to Ets-1, MMP-1 and MMP-9 expression. Int J Mol Med 8: 149-154, 2001

82. Behrens P, Mathiak M, Mangold E, Kirdorf S, Wellmann A, Fogt F, Rothe M, Florin A and Wernert N: Stromal expression of invasion-promoting, matrix-degrading proteases MMP-1 and -9 and the Ets 1 transcription factor in HNPCC carcinomas and sporadic colorectal cancers. Int J Cancer 107: 183-188, 2003.

83. Patterson BC and Sang QA: Angiostatin-converting enzyme activities of human matrilysin (MMP-7) and gelatinase B/type IV collagenase (MMP-9). J Biol Chem 272: 28823-28825, 1997.
84. Suzuki M, Raab G, Moses MA, Fernandez CA and Klagsbrun M: Matrix metalloproteinase-3 releases active heparin-binding EGF-like growth factor by cleavage at a specific juxtamembrane site. J Biol Chem 272: 31730-31737, 1997.

85. Whitelock JM, Murdoch AD, Iozzo RV and Underwood PA: The degradation of human endothelial cell-derived perlecan and release of bound basic fibroblast growth factor by stromelysin, collagenase, plasmin, and heparanases. J Biol Chem 271: 10079-10086, 1996. 